\title{
Identification of best spray schedules for propiconazole fungicide against spot blotch disease in Wheat
}

\section{Deepak Bhandari}

Nepal Agricultural Research Council, Khumaltar, Lalitpur, Nepal

$\triangle$ Corresponding author: b.deepak359 [@] gmail.com

Article Received: 17.09.17; Revised: 04.12.17; Published online: 14 December 2017.

\begin{abstract}
Spot blotch disease caused by Bipolaris sorokiniana (Sacc.) shoem. is one of the most destructive diseases of wheat (Triticum aestivum L.) in plain areas of Nepal. Triazoles fungicides are expensive but effective against the disease. The experiment was conducted to identify the most efficient spray schedules of Tilt (Propiconazole $25 \mathrm{ec}$ ) fungicide against spot blotch disease in wheat. The experiment was carried out at National Wheat Research Program, Bhairahawa, Nepal in Randomized Complete Block Design with three replications and 12 treatments. The treatments comprised of frequencies of spray, days for spray after the seeding date and intervals between two sprays. Both two and three sprays of Propiconazole fungicide remarkably reduced the severity of spot blotch disease, but single spray hadn't any effect on spot blotch disease. Two sprays at 70 and 85 days after seeding (DAS) were the most effective among the tested treatments against spot blotch disease. The spray of fungicide at early crop stage (before 50 DAS) and very late crop stage (after 80 DAS) had less effect on spot blotch disease AUDPC. There weren't significant differences in spot blotch AUDPC between the spray schedules having 10 and 15 days intervals. Grain yield and Thousand Grain Weight (TGW) were significantly higher in some treatments having tilt spray as compare to the control. The single spray had no impact on yield increments; however, two and three sprays significantly increased the grain yield. Cost effective assay of Propiconazole against spot blotch disease shows that one, two and three sprays of fungicide are beneficial for both seed and grain production purposes under Nepalese conditions. In conclusion, spray of Propiconazole fungicide at appropriate time periods manages the spot blotch disease, increases the yield and is cost effective in both seed and grain production schemes for the farmers of Nepal.
\end{abstract}

Key Words: AUDPC, Bipolaris, Cost effectiveness, Frequency and Tilt

Cite Article: Bhandari, D. (2017). Identification of best spray schedules for Propiconazole fungicide against spot blotch disease in Wheat. Journal of Bioscience and Agriculture Research,15(02), 12871293. Crossref: https://doi.org/10.18801/jbar.150217.159

Article distributed under terms of a Creative Common Attribution 4.0 International License.

\section{Introduction}

Spot blotch disease (caused by Cochliobolus sativus (Ito \& Kurib.) Drechsler ex. Dastur (anamorph: Bipolaris sorokiniana) is a major constraint for profitable wheat production in whole terai regions of Nepal. The disease occurs every year in warm wheat growing areas of Nepal in moderate to severe form (Duveiller et al., 2005). Lack of durable resistant genotypes, less use of fungicides and 
inefficiency of other control measures are responsible for the regular epidemic of the disease (Sharma et al., 2007; Sharma et al., 2004; Sharma and Duveiller, 2004). The losses due to the disease in Nepal ranged from 23 - $40 \%$ depending on genotypes and other environmental factors (Shrestha et al., 1998; Bhandari and Tripathi, 2005; Sharma and Duveiller, 2006). Resistant genotypes, foliar spray of fungicides and nutrients management are effective against the disease (Duveiller, 2002; Regmi et al., 2002; Bhandari, 2010). Application of Triazoles fungicides can suppress the disease effectively (Bhandari and Gharti, 2002; De- Viedma and Kohli, 1997). Three sprays of propiconazole fungicide @ $2 \mathrm{ml} /$ liter water at two weeks intervals effectively control the disease (Singh et al., 1997; SharmaPoudyal et al., 2005). Propiconazole can reduce the spot blotch disease severity (AUDPC) up to 75 percent depending on level of disease epidemics (De- Viedma and Kohli, 1997). However, the cost effectiveness of use of propiconazole fungicides in wheat crop grown by marginal farmers of South Asia is debatable. Singh (2003) advocated that use of propiconazole fungicide on commercial crop is not an economical option in India. Similarly, Nepalese farmers are reluctant to use the propiconazole fungicides against the disease, because the fungicide is comparatively expensive, and there isn't any study on cost effectiveness of the fungicides against the spot blotch disease under our socio-economic conditions. Therefore, this study was conducted to identify the cost effectiveness and the most efficient spray schemes of Tilt (Propiconazole) fungicide against spot blotch disease in wheat under Nepalese conditions.

\section{Materials and Methods}

The experiment was carried out at National Wheat Research Program, Bhairahawa, Nepal in Randomized Complete Block Design with three replications and 12 treatments during 2010-2011. The treatments comprised of frequencies of spray, days of spray after the seeding date and intervals between two sprays. Four frequencies of sprays (single spray, two sprays, three sprays and four sprays) at various dates after seeding (DAS) of crop plants at three different days of interval (10 days, 15 days and 20 days) were the various treatments. Tilt (Propiconazole 25\% ec) @ $1.5 \mathrm{ml} / \mathrm{liter}$ water ( $900 \mathrm{ml}$ fungicide /ha) was used as test fungicide. One of a new genotype BL 3063 was grown in both the years. Half of the nitrogen and full dose of phosphorus and potash was applied as basal dose and remaining half dose of nitrogen was applied after 25 days of seeding as top dress. Ten main tillers in each plot were randomly selected and tagged prior to scoring disease severity. Severity of disease was recorded by visually assessing the percent diseased leaf area on the flag leaf and penultimate leaf of tagged tillers as previously used by Dubin et al. (1997). Three scores were recorded at 7 days intervals after the heading stage of the crop. Area Under Disease Progress Curve (AUDPC) was calculated following the formula given by Das et al. (1992). Yields and thousand-grain weight were recorded for analysis of yield attributes.

\section{Results and Discussion}

\section{Effects on disease severity}

There were significant differences $(\mathrm{P}<0.05)$ on spot blotch disease AUDPC level among the tested treatments (Table 01). Propiconazole significantly reduced the spot blotch disease severity; however, all the treatments were not effective against the disease. Frequency of fungicide had paramount role in disease suppression. The frequencies of fungicides having two, three and four sprays had effectively suppressed the disease, which signifies that at least two sprays of fungicide are needed to manage the disease effectively. The result agrees with the results of various previous workers (Shrestha et al., 1998; Singh et al., 1997). There were non significant differences between two and three sprays of fungicides, which indicate that two sprays of fungicide are adequate to suppress the disease. Single application of fungicide has non significant difference with control (no spray) treatments, which point out that one spray is unable to suppress the disease effectively. 
Table 01. Level of spot blotch AUDPC on treatments having various combinations of frequencies and time of application of propiconazole fungicide tested at Bhairahawa, Nepal

\begin{tabular}{lll}
\hline Treatment No. & Spray schedule (Days after seeding) & Av. AUDPC \\
\hline 5 & $70-85$ & $207 \mathrm{a}$ \\
3 & $50-70-85$ & $245 \mathrm{ab}$ \\
2 & $40-60-80$ & $257 \mathrm{ab}$ \\
4 & $65-80-95$ & $264 \mathrm{ab}$ \\
6 & $75-85-95$ & $291 \mathrm{abc}$ \\
9 & $80-95$ & $314 \mathrm{abc}$ \\
7 & $80-90$ & $316 \mathrm{abc}$ \\
8 & $75-90$ & $340 \mathrm{bcd}$ \\
1 & $35-55-75-95$ & $341 \mathrm{bcd}$ \\
10 & 85 & $364 \mathrm{bcd}$ \\
11 & 90 & $404 \mathrm{~cd}$ \\
12 & Control & $448 \mathrm{~d}$ \\
\hline & $P$. value & 0.037 \\
& LSD & 129.8 \\
& CV & 24.3 \\
\hline
\end{tabular}

Similarly, time of application of fungicide had significant $(\mathrm{P}<0.05)$ effect on disease suppression (Table -01); which clears that the application of fungicide at crucial growth stages of the crop has paramount importance in disease inhibition. Spray of fungicide before heading and at later stage of crop growth was less effective against the disease; however, the result is not agreed with Mehta and Igarashi (1985) who advocated applying the first spray at 45-55 DAS. Two sprays at 70-85 days after seeding had the lowest disease severity. The treatments having time of application around 80 days after seeding was very effective, which indicate that at least one spray must be provided around 80 DAS. Similarly, there were non significant differences between the sprays having 10 days interval and 15 days interval. The result clears that 15 days interval should be preferred over 10 day's intervals, because it will reduce the overall expense and burden of fungicide spray. Application of fungicides at 15 days interval was advocated by some previous workers (Singh et al., 1997; Shrestha et al., 1998).

The percent reduction on spot blotch AUDPC due to the application of propiconazole was ranged from 10 - 54 percent depending on frequencies and days of sprays after seeding (Figure 01). Up to 63 percent reduction of foliar blight AUDPC due to the application of Triazole fungicides was reported by Sharma-Poudyal et al. (2005). Both the treatments having single spray of propiconazole, and were applied at later stages of crop growth reduced the disease AUDPC by less than $20 \%$. It clears that late application and single spray of fungicide is less effective against the disease. In contrast, the other treatments having two and three sprays of fungicides applied during various growth stages of the crop reduce the disease AUDPC by more than $20 \%$. It signifies that at least two sprays are necessary to reduce the disease effectively. The result is agreed with the out comes of several previous workers (De-Viedma and Kohli, 1997; Sharma-Poudyal et al., 2005). 


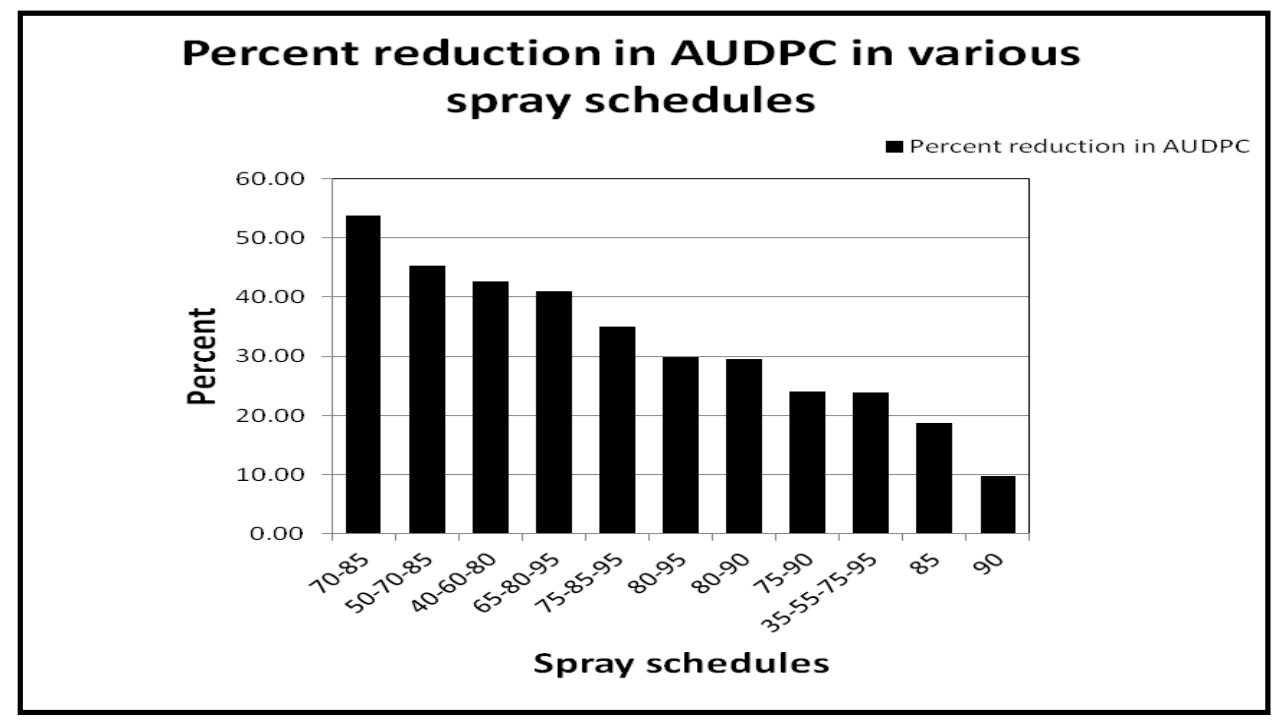

Figure 01. Percent reduction in AUDPC in the treatments having different spray schedules of Propiconazole fungicide tested at Bhairahawa, Nepal.

\section{Effects on yield parameters}

There were significant differences $(\mathrm{P}<0.05)$ in thousand grain weights $(\mathrm{TGW})$ among the treatments (Table 02). The TGW was significantly lower in the treatments having one and two sprays applied during later stages of the crop growth as compare to the treatments which had two and three sprays applied during mid to before later stages of crop growth. It signifies that spray of fungicide at optimum time increased the TGW by reducing the disease AUDPC. Higher TGW in treatments having lower AUDPC and lower TGW in treatments having higher AUDPC indicates the negative corelations between TGW and disease AUDPC level. The outcome accords various previous reports in which the negative correlation of TGW with spot blotch AUDPC was promoted (Sharma et al., 2005; Sharma and Duveiller, 2004).

Table 02. Thousand grain weight (TGW) on different treatments having various combinations of spray frequencies and time of application of propiconazole fungicide tested at Bhairahawa, Nepal

\begin{tabular}{ll}
\hline Treatments & TGW (gram) \\
\hline $70-85$ & $40.50 \mathrm{a}$ \\
$50-70-85$ & $39.33 \mathrm{ab}$ \\
$40-60-80$ & $39.17 \mathrm{ab}$ \\
$75-85-95$ & $39.00 \mathrm{ab}$ \\
$35-55-75-95$ & $39.00 \mathrm{ab}$ \\
$80-90$ & $38.50 \mathrm{ab}$ \\
$65-80-95$ & $38.17 \mathrm{~b}$ \\
$80-95$ & $37.50 \mathrm{bc}$ \\
90 & $37.50 \mathrm{bc}$ \\
$75-90$ & $36.67 \mathrm{bc}$ \\
85 & $36.67 \mathrm{bc}$ \\
Control & $35.33 \mathrm{c}$ \\
\hline$P$. value & 0.005 \\
LSD & 2.23 \\
CV & 3.5 \\
\hline
\end{tabular}

The effect of fungicide on grain yield was significant $(\mathrm{P}<0.05)$ (Table 03). There were non significant differences among the treatments for yield having no spray and one spray applied at later stage of the crop growth. It supports that spray of chemical at later stages of crop growth could not increase the yield considerably by suppressing the spot blotch disease. On the other hand, most of the treatments having two, three and four sprays of propiconazole had significantly higher yield than the control plot. 
It indicates that two, three and four sprays of propiconazole fungicide increased the wheat yield by reducing the spot blotch disease considerably. The result agrees with the outcome of De- Viedma and Kohli (1997). The percent increase in grain yield was ranged from 18-43\% depends on level of frequencies and time of application; nevertheless, the highest increase in grain yield due to the application of fungicide was reported up to 83\% (Sharma-Poudyal et al., 2005).

Table 03. Grain yield on different treatments having various combinations of frequencies and time of application of propiconazole fungicide tested at Bhairahawa, Nepal

\begin{tabular}{lll}
\hline Treatments & Yield (Kg/ha) & Percent increase in yield \\
\hline $50-70-85$ & $3244 \mathrm{~d}$ & 43.50 \\
$70-85$ & $2956 \mathrm{~cd}$ & 37.99 \\
$75-90$ & $2906 \mathrm{bcd}$ & 36.92 \\
$40-60-80$ & $2739 \mathrm{bcd}$ & 33.08 \\
$65-80-95$ & $2639 \mathrm{bcd}$ & 30.54 \\
$75-85-95$ & $2583 \mathrm{bcd}$ & 29.04 \\
$35-55-75-95$ & $2533 \mathrm{bc}$ & 27.64 \\
$80-90$ & $2533 \mathrm{bc}$ & 27.64 \\
$80-95$ & $2444 \mathrm{abc}$ & 25.00 \\
85 & $2428 \mathrm{abc}$ & 24.51 \\
90 & $2244 \mathrm{ab}$ & 18.32 \\
Control (No spray) & $1833 \mathrm{a}$ & 0.00 \\
\hline$P$. value & 0.044 & \\
LSD & 692.5 & \\
$C V$ & 15.8 & \\
\hline
\end{tabular}

\section{Cost effectiveness assay of propiconazole}

The cost effectiveness assay of propiconazole fungicide (@900 ml/ha) against spot blotch disease on wheat shows that the spray of fungicide is beneficial over non spray for both seed and grain production purposes (Table 04).

Table 04. Cost effective assay of propiconazole applied at various frequencies and at various growth stages of wheat crop for seed and grain production purposes at Bhairahawa, Nepal

\begin{tabular}{lcccccc}
\hline Treatment & $\begin{array}{l}\text { Yield gain } \\
\text { over control } \\
\text { (kg/ha) }\end{array}$ & $\begin{array}{l}\text { Gross profit } \\
\text { /ha (seed: } \\
\text { 30rs/kg) }\end{array}$ & $\begin{array}{l}\text { Gross profit } \\
\text { /ha (grain: } \\
\text { 17rs/kg) }\end{array}$ & $\begin{array}{l}\text { Expense on } \\
\text { fungicide (3600 } \\
\text { rs/ spray / ha) }\end{array}$ & $\begin{array}{l}\text { Net profit } \\
\text { /ha (seed } \\
\text { production) }\end{array}$ & $\begin{array}{l}\text { Net profit } \\
\text { /ha (grain } \\
\text { production) }\end{array}$ \\
\hline $50-70-85$ & 1411 & 42330 & 23987 & 10800 & 31530 & 13187 \\
$70-85$ & 1123 & 33690 & 19091 & 7200 & 26490 & 11891 \\
$75-90$ & 1073 & 32190 & 18241 & 7200 & 24490 & 11041 \\
$40-60-80$ & 906 & 27180 & 15402 & 10800 & 16380 & 4602 \\
$65-80-95$ & 806 & 24180 & 13702 & 10800 & 13380 & 2902 \\
$75-85-95$ & 750 & 22500 & 12750 & 10800 & 11700 & 1950 \\
$80-90$ & 700 & 21000 & 11900 & 7200 & 13800 & 4700 \\
$35-55-$ & 700 & 21000 & 11900 & 14400 & 6600 & -2500 \\
$75-95$ & & & & & & 11130 \\
$80-95$ & 611 & 18330 & 10387 & 7200 & 14730 & 6787 \\
90 & 611 & 18330 & 10387 & 3600 & 14250 & 6515 \\
85 & 595 & 17850 & 10115 & 3600 & 0 & 0 \\
Control & 0 & 0 & 0 & 0 & & \\
\hline
\end{tabular}

Results show that one, two and three sprays of propiconazole are lucrative for farmers, but four sprays of propiconazole are unprofitable. The economic analysis shows that application of two to three 
sprays of fungicides around 50-85 days after seeding is the best from profit point of view. Despite the non significant disease suppression by single spray, it is more beneficial than some of the two and three sprays applied at later stage of the crop growth. It suggests that small wheat growers can increase their income from wheat crop by applying even one spray of propiconazole at appropriate stage of crop growth.

\section{Conclusion}

Application of Propiconazole fungicide @ $900 \mathrm{ml} / \mathrm{ha}$ (1.5 ml/liter water) is advantageous for both seed and grain production purposes against spot blotch disease under Nepalese conditions. Application of two sprays at 70 and 85 days after seeding was most efficient for suppression of the disease, increment of yield and obtaining higher incomes from wheat productions. The application of one, two and three sprays of propiconazole is cost effective against spot blotch disease, however four sprays of propiconazole is unprofitable for grain production purpose.

\section{Acknowledgement}

Author is grateful to Nepal Agricultural Research Council (NARC) for financial support to conduct the research efficiently. Thanks are also provided to staffs of National Wheat Research Program, NARC for their help in conduction of experiment.

\section{References}

[1]. Bhandari, D. (2010). Influence of long-term use of organic and inorganic nutrients on HLB disease of wheat under Rice-Wheat cropping pattern. Journal of Phytology, 2 (2), 125-135.

[2]. Bhandari, D. and Gharti, D. B. (2002). Foliar blight management with potash and nitrogen fertilizers. Proceedings of Wheat research papers presented at 25th National winter crops research workshop. Volume 1: Wheat. National Wheat Research Program, Bhairahawa, Nepal. pp. 132-135.

[3]. Bhandari, D. and Tripathi, J. (2005). Intensity of Helminthosporium leaf blight of wheat in different methods of planting. In proceedings of $26^{\text {th }}$ National winter crops research workshop, Nepal Agricultural Research Council held at Khumaltar, Kathmandu, Nepal. pp. 181-187.

[4]. Das, M. K., Rajaram, S., Mundt, C. C. and Kronstad, W. E. (1992). Inheritance of slow rusting resistance to leaf rust in wheat. Crop Science, 32, 1452-1456.

https://doi.org/10.2135/cropsci1992.0011183X003200060028x

[5]. De-viedma, L. Q. and Kohli, M. M. (1997). Spot blotch and Tan spot of wheat in Paraguay. In: E. Duveiller, H. J. Dubin, J. Reeves and A. McNab (eds.), Helminthosporium blight of wheat: Spot blotch and Tan spot. CIMMYT, Mexico, D. F. pp. 126-133.

[6]. Dubin, H. J., Arun, B. S., Begam, N., Bhatta, M., Dhari, R., Goel, L. B., Joshi, A. K., Khanna, B. M., Malakar, P. K., Pokhrel, D. R., Rahaman, M. M., Saha, N. K., Shaheed, M. A., Sharma, R. C., Singh, A. K., Singh, R. M., Singh, R. V., Vargas, M. and Verma, P. C. (1997). Results of the South Asia regional Helminthosporium leaf blight and yield experiments, 1993-94. In: E. Duveiller, H. J. Dubin, J. Reeves and McNab, A. (eds.), Helminthosporium blight of wheat: Spot blotch and Tan spot. CIMMYT, Mexico, D. F. pp. 182-187.

[7]. Duveiller, E. 2002. Helminthosporium blights of wheat: Challenges and strategies for a better disease control. In: Advances of Wheat Breeding in China. China Science and Technology Press, Jinan, Shandong, People's Republic of China. pp. 57-66.

[8]. Duveiller, E., Kandel, Y. R., Sharma, R. C. and Shrestha, S. M. 2005. Epidemiology of foliar blights (spot blotch and tan spot) of wheat in the plains bordering the Himalayas. Phytopathology, 95, 248-256. https://doi.org/10.1094/PHYTO-95-0248

[9]. Mehta, Y. R. and Igarashi, S. (1985). Chemical control measures for major diseases of wheat with special attention to spot blotch. In: Proceedings of the international symposium. pp. 196200. Mexico. DF. CIMMYT. p. 364.

[10]. Regmi, A. P., Ladha, J. K., Pasuquin, E. M., Pathak, H., Hobbs, P. R., Shrestha, L. L., Gharti, D. B. and Duveiller, E. 2002. The role of potassium in sustaining sustaining yields in a long-term rice-wheat experiment in the Indo-Gangetic plains of Nepal. Biology and Fertility of Soils, 36, 240-247. https://doi.org/10.1007/s00374-002-0525-x 
[11]. Sharma, R. C. and Duveiller, E. (2004). Effect of Helminthosporium leaf blight on performance of timely and late-seeded wheat under optimal and stressed levels of soil fertility and moisture. Field Crops Research, 89, 205-218. https://doi.org/10.1016/j.fcr.2004.02.002

[12]. Sharma, R. C. and Duveiller, E. 2006. Spot blotch continues to cause substantial grain yield reductions under resource limited farming conditions. J. Phytopathol, 154, 482-488.

https://doi.org/10.1111/j.1439-0434.2006.01134.x

[13]. Sharma, R. C., Duveiller, E. and Ortiz-Ferrara, G. 2007. Progress and challenge towards reducing wheat spot blotch threat in the Eastern Gangetic Plains of South Asia: Is climate change already taking its toll? Field Crops Research, 103, 109-118.

https://doi.org/10.1016/j.fcr.2007.05.004

[14]. Sharma, R. C., Duveiller, E., Ahmed, F., Arun, B., Bhandari, D., Bhatta, M.R., Chand, R., Chaurasiya, P.C.P., Gharti, D.B., Hossain, M. H., Joshi, A. K., Mahto, B. N., Malaker, P. K., Reza, M. A., Rahman, M., Samad, M. A., Shaheed, M. A., Siddique, A. B., Singh, A. K., Singh, K. P., Singh, R. N. and Singh, S. P. 2004. Helminthosporium leaf blight resistance and agronomic performance of wheat genotypes across warm regions of South Asia. Plant Breed, 123, 520-524.

https://doi.org/10.1111/j.1439-0523.2004.01006.x

[15]. Sharma, S., Duveiller, E., Basnet, R., Karki, C. B. and Sharma, R. C. (2005). Effect of Potash fertilization on Helminthosporium leaf blight severity in wheat, and associated increase in grain yield and kernel weight. Field Crop Research. 93, 142-150.

https://doi.org/10.1016/j.fcr.2004.09.016

[16]. Sharma-Poudyal, D., Duveiller, E. and Sharma, R. C. (2005). Effects of seed treatment and foliar fungicides on Helminthosporium leaf blight and on performance of wheat in warmer growing conditions. Journal of Phytopathology, 153(7-8), 401-408.

https://doi.org/10.1111/j.1439-0434.2005.00992.x

[17]. Shrestha, K. K., Timila, R. D., Mahato, B. N. and Bimb, H. P. (1998). Disease incidence and yield loss due to foliar blight of wheat in Nepal. In: E. Duveiller, H. J. Dubin, J. Reeves, and McNab, A. (eds.), Helminthosporium Blights of Wheat: Spot blotch and Tan spot. CIMMYT, Mexico, D. F. pp. 67-72.

[18]. Singh, D. P. (2003). Leaf blight of wheat caused by Bipolaris sorokiniana in India: Importance, epidemiology and management strategies for sustaining wheat production in hot and humid climate of eastern India. In: Rasmussen, J. B., T. L. Friesen and S. Ali. (eds.), Proceedings of the fourth International wheat Tan spot and Spot blotch workshop, North Dakota State University, Fargo, USA. pp. 79 - 85.

[19]. Singh, R. V., Singh, A. K. and Singh, S. P. (1997). Distribution of pathogens causing foliar blight of wheat in India and neighboring countries. In: E. Duveiller, H. J. Dubin, J. Reeves and McNab, A. (eds.), Helminthosporium blight of wheat: Spot blotch and Tan spot. CIMMYT, Mexico, D. F. pp. 59-62.

\section{HOW TO CITE THIS ARTICLE?}

Crossref: https://doi.org/10.18801/jbar.150217.159

\section{APA (American Psychological Association)}

Bhandari, D. (2017). Identification of best spray schedules for Propiconazole fungicide against Spot blotch disease in Wheat. Journal of Bioscience and Agriculture Research,15(02), 1287-1293.

\section{MLA (Modern Language Association)}

Bhandari, D. "Identification of best spray schedules for Propiconazole fungicide against Spot blotch disease in Wheat". Journal of Bioscience and Agriculture Research, 15.02(2017): 1287-1293.

\section{Chicago and or Turabian}

Bhandari, D. "Identification of best spray schedules for Propiconazole fungicide against Spot blotch disease in Wheat". Journal of Bioscience and Agriculture Research,15 no.02(2017):1287-1293. 